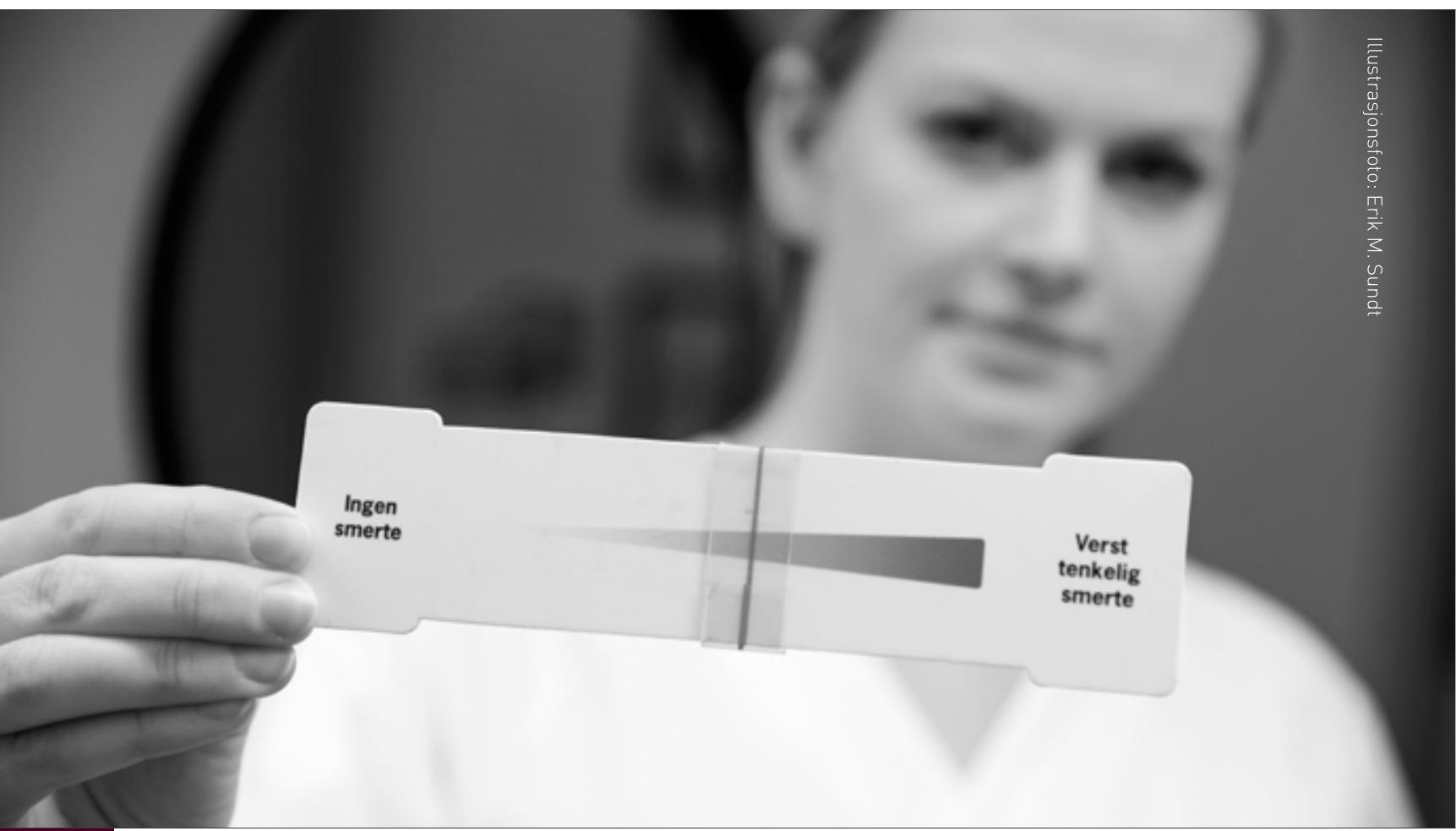

Bakgrunn: Smerter er fortsatt utilstrekkelig behandlet til tross for $\varnothing \mathrm{kt}$ kunnskap. Forskning viser at sykepleieres kunnskaper og holdninger til smerter er mangelfull, men vesentlig for tilfredsstillende smertelindring av pasienten.

Hensikt: $\AA$ få økt kunnskap om sykepleieres og sykepleiestudenters kunnskaper om og holdninger til smerter og smertelindring hos voksne.

Metode: En tverrsnittstudie der data ble samlet inn ved hjelp av den

Nurses' and students knowledge and attitude regarding pain in adults

Background: Research reveals that nurses' knowledge and attitudes are important for sufficient pain relief to the patient. By identifying areas of improvement, efforts can be made to improve pain management in nursing.

Objective: To survey nurses' and nurse students' knowledge and attitudes regarding pain and pain relief.

Methods: A cross-sectional study norske versjonen av kartleggingsverktøyet Nurses' Knowledge and Attitudes Survey Regarding Pain (NKAS-N). NKAS-N inneholder 39 spørsmål vedrørende smertehåndtering og smertelindring. Studien inkluderte totalt 200 sykepleiere og sykepleiestudenter fra ett universitetssykehus og én høyskole.

Resultater: Det endelige utvalget besto av 165 deltakere og ga en svarprosent på 83 prosent. Prosentvis gjennomsnittlig riktige svar var 71,1 prosent for sykepleierne og 58,5 prosent for sykepleiestuden- tene. Sykepleierne skåret signifikant bedre enn sykepleiestudentene $(p<0,001)$.

Konklusjon: Både sykepleiere og sykepleiestudenter hadde gode kunnskaper om smertelindring på noen områder. Studien avdekket imidlertid at sykepleiere og sykepleiestudenter var engstelige for respirasjonsdepresjon og opioidavhengighet. Videre var det et gap mellom teoretisk kunnskap og praktisk handling synliggjort gjennom to pasienthistorier. Det er et behov for å styrke kompetansen om smertehåndtering. where the Norwegian version of the Nurses' Knowledge and Attitudes Survey Regarding Pain (NKAS-N) was used. NKAS-N consists of 39 questions which address general pain management and pain relief. The study included 200 nurses and nurse students at one university hospital and one university college.

Results: The final sample consisted of 165 participants giving a response rate of $83 \%$. The average of correct answers was $71.1 \%$ for the nurses and $58.5 \%$ for the nurse students.
The nurses scored significantly higher than the nurse students ( $p<$ 0.001)

Conclusion: The nurses and nurse students had an acceptable level of theoretical knowledge regarding pain relief in some areas. Even so, the study revealed that both groups were anxious about respiratory depression and opioid dependency. Further, there was a gap between what the nurses

Key words: Pain, pain management, nurse, knowledge, attitude. 


\section{Sykepleieres og studenters kunnskap og holdninger til smerter og smertelindring hos voksne}

Forfattere: Tone Høilo Granheim, Kari Raaum, Knut-Andreas Christophersen og Alfhild Dihle

\section{NØKKELORD}

- Smerte

- Smertelindring

- Sykepleie

- Kunnskap

- Holdning

\section{INTRODUKSJON}

Å lindre smerter har alltid vært viktig innenfor pleie av syke. Den norske legeforeningen (1) slår fast at smerte er en subjektiv opplevelse i tråd med International Association for the Study of Pain (IASP) (2). IASP vektlegger at pasienten blir trodd på og at ingen andre enn pasienten kan bestemme om smerten eksisterer eller dens intensitet $(2,3)$. Ifølge Legeforeningen bør alle avdelinger som ivaretar kirurgiske pasienter ha rutiner for smertebehandling. Målet for postoperativ smertelindring er ikke å overskride 3 på numerisk rangskala (NRS-11), der 0 er ingen smerter og 10 er verst tenkelige smerter (1).

Sykepleiere arbeider nær pasienten og har dermed en unik mulighet til å kartlegge pasientens smertetilstand, samt vurdere effekten av smertebehandlingen. Det å smertelindre en pasient er en utfordrende oppgave som krever oppdaterte kunnskaper, tilfredsstillende ferdigheter, samt holdninger som frembringer tillit, omsorg og en overbevist tro på det pasienten sier $(4,5)$.

I denne artikkelen er fokuset på medikamentell smertebehandling etter kirurgiske inngrep og ved alvorlig kreftsykdom. Disse tilstandene krever ofte behandling med opioider. Vurdering av smerteintensitet og administrering av opioider er viktige oppgaver som sykepleieren har ansvaret for $(6,7)$. Forskning viser imidlertid at sykepleiernes holdninger og kunnskaper er viktige faktorer som kan hindre god smertelindring, og at det fremdeles eksisterer myter og misoppfatninger om bruk av opioider $(5,8-13)$. Mange sykepleiere frykter for avhengighet av opioider og respirasjonsdepresjon grunnet overdosering med opioider, noe som kan føre til at pasienter ikke blir godt nok smertelindret (7,14-16). Å underbehandle smerter er uetisk $(16,17)$. Av den grunn er det viktig å rette oppmerksomheten mot sykepleierens kunnskaper om og holdninger til smerter. Funnene fra en norsk studie (18) viste at leger og sykepleiere rapporterte at pasientene ofte eller veldig ofte

\section{Hva tilfører artikkelen?}

Studien viser at sykepleiere og studenter trenger å styrke sin kompetanse om smertehåndtering på flere områder.

\section{Mer om forfatterne:}

Tone Høilo Granheim er sykepleier ved Gastrokirurgisk avdeling, Akershus universitetssykehus HF. Kari Raaum er assisterende utdanningsleder og barnesykepleier i Stab forskning, innovasjon og utdanning, OUS. Knut-Andreas Christophersen er universitetslektor i statistikk ved Det samfunnsvitenskapelige fakultet, UiO. Alfhild Dihle er assisterende utdanningsleder og førsteamanuensis ved $\mathrm{H} \varnothing \mathrm{gsk}$ len i Oslo og Akershus. Kontaktperson: alfhild.dihleahioa.no. 
oppnådde tilfredsstillende postoperativ smertebehandling ved deres avdeling. En høy andel av utvalget rapporterte lav egenkompetanse om behandling av nevropatisk smerte, mens andelen var høyere når det gjaldt egen kompetanse om behandling av nociseptive smerter. Det var ingen signifikante forskjeller mellom profesjonene med hensyn til vurdering av egen kompetanse. I en norsk studie fra 1998 (19), vurderte leger og sykepleiere egen kunnskap og kompetanse om smerter hos kreftpasienter og pasienter med kronisk smerte. Sykepleierne vurderte sin egen kompetanse lavere enn legene med hensyn til nociseptive og nevrogene smerter og høyere når det gjaldt psykiske og sosiale dimensjoner

\section{Å underbehandle smerter er vetisk.}

ved smerte, mens det ikke var noen forskjeller når det gjaldt eksistensielle eller åndelige dimensjoner (19). I begge studiene (18-19) var det helsepersonellets egen vurdering av egen kompetanse som ble kartlagt. Det er ikke funnet norske studier som kartlegger kunnskaper og holdninger til smerte hos voksne ved hjelp av et validert kartleggingsverktøy.

Hensikten med studien var å beskrive sykepleieres og sykepleiestudenters kunnskaper om og holdninger til smerter hos voksne pasienter inneliggende på kirurgisk avdeling.

\section{METODE Utvalg}

I denne deskriptive tverrsnittsundersøkelsen ble 200 sykepleiere og sykepleiestudenter inviterte til å delta. Av disse var 114 sykepleiere ved fem kirurgiske sengeposter fra et universitetssykehus, og 86 var sykepleiestudenter i siste studieår ved en høgskole. Sykepleiestudentene $\mathrm{i}$ siste studieår hadde hatt smerteundervisning, samt gjennomført kirurgisk praksis. De hadde derfor et teoretisk og et visst praktisk grunnlag for å svare på spørsmålene. Vi hadde interesse av å se hva de hadde lært, mindre enn et halvt år før de skulle begynne i jobb som sykepleiere.

\section{Instrumenter}

Spørreskjemaet Nurses' Knowledge and Attitudes Survey Regarding Pain (NKAS) ble utviklet i 1987 av Ferrell og McCaffery for å vurdere sykepleieres og andre helsearbeideres kunnskaper om og holdninger til smertebehandling. NKAS brukes også til å evaluere opplærings- eller utdanningsprogrammer (20). Skjemaet bygger på standarder fra American Pain Society, Agency for Health Care Policy and Research og Verdens helseorganisasjon (20). Skjemaet tester kunnskaper og holdninger gjennom spørsmål og utsagn som krever eksakte svar. Det grunnleggende ved NKAS er at for å lykkes i smertelindringen, må sykepleieren være lydhør overfor pasientens subjektive opplevelse av smertene.

NKAS ble oversatt til norsk etter tillatelse fra forfatterne. Oversettelsen ble utført etter gjeldende internasjonale retningslinjer inkludert reoversettelse ved to profesjonelle oversettere (21-23). Det var avgjørende at de oversatte spørsmålene målte det originalspørsmålene var konstruert for å måle (21). Medikamentelle tilpasninger ble konferert med lege og farmasøyt. NKAS-N ble vurdert til å ha tilfredsstillende reliabilitet og validitet (24).

NKAS-N består av 39 spørsmål fra områdene smertevurdering, smertehåndtering $\mathrm{og}$ medikamentell smertelindring. I de første 21 spørsmålene skal man ta stilling til om et utsagn er sant eller usant. De neste 14 er multiple choice med tre til fem svaralternativer hvor kun ett er riktig. De fire siste spørsmålene er basert på to pasienthistorier der sykepleieren skal vurdere pasientens smerteintensitet, etter at pasienten selv har bedømt sine smerter på NRS-11. Til slutt skal sykepleieren angi hvor mye morfin hun ville gitt ut fra fire faste svaralternativer. Bruk av de to pasienthistoriene er en metode for å komme nærmere en reell situasjon der man skal benytte kunnskap i smertevurderingen av en pasient. For hvert spørsmål blir det gitt 0 poeng for galt svar og 1 poeng for rett svar, slik at maksimal oppnåelig poengsum er 39 poeng. Antall korrekte svar for hvert utfylte skjema kalles sumskår. Det tar 20-25 minutter å fylle ut skjemaet. Deltakerne svarte også på spørsmål om alder, utdanning, erfaring og stillingsbrøk.

\section{Datainnsamling}

Datainnsamlingen ble utført primo 2009. Sykepleierne fikk informasjon om studien på personalmøter og mail via sykehusets intranett. Det ble understreket at alle skulle svare på alle spørsmål og velge dét alternativet de trodde var rett svar. Sykepleierne fylte ut skjemaet inklusive demografiske data i arbeidstiden. Studentene fikk informasjon om studien på intranett og muntlig informasjon ble gitt i forkant av utfyl- 
lingen av skjemaene, som ble gjennomført i en skoletime.

\section{Forskningsetiske} overveielser

Ved gjennomføring av prosjektet ble forskningsetiske retningslinjer fulgt (25). Prosjektet, inklusive informasjonsskrivene til sykepleiere og sykepleiestudenter, ble forhåndsgodkjent av Personvernombudet for forskning hos Norsk samfunnsvitenskapelig datatjeneste (NSD). Det ble innhentet tillatelse til gjennomføring av undersøkelsen ved sykehus og høyskole. I informasjonsskrivene ble konfidensialitet og frivillig deltakelse understreket. I de demografiske dataene ble alder kategorisert og kjønn ikke registrert, i den hensikt å ivareta deltakernes anonymitet.

\section{Statistiske analyser}

Dataene ble analysert ved bruk av SPSS versjon 17. Deskriptiv statistikk ble benyttet for å analysere bakgrunnsdataene. Gjennomsnittlig sumskår ble beregnet i gruppene med sykepleiere og sykepleiestudenter. Forskjellen i gjennomsnittlig sumskår mellom de to gruppene ble undersøkt med Student t-test. Signifikansnivået ble satt til 5 prosent $(\mathrm{p}<0,05)$. Det ble beregnet prosentvise korrekte svar på hvert av de 39 spørsmålene både i det samlede utvalget og i hver av de to gruppene.

\section{RESULTATER}

\section{Demografiske data}

Totalt 165 (83 prosent) besvarte spørreskjemaet, fordelt på 82 (49,7 prosent) sykepleiere og 83 (50,3 prosent) sykepleiestudenter. Studentene hadde ingen arbeidserfaring som sykepleiere, derfor ble kun alder registrert.

Tabell 1a: Karakteristikk av sykepleierne ( $N=82)$

\section{Alder (år)}

$<24$

$24-29$

$(26,8)$

$30-39$

$(43,9)$

40-49

$(24,4)$

$50-59$

Missing

\section{Stillingsbrøk}

$75-100 \%$

$(87,8)$

$50-74,9 \%$

$<50 \%$

Missing

Mean

(SD)

\section{Arbeidserfaring (år)}

Erfaring som sykepleier

$7,2 \quad(5,6)$

Erfaring fra kirurgisk avdeling

Erfaring fra onkologisk avdeling

$5,5 \quad(5,0)$

Erfaring ved nåværende kirurgisk avdeling

$4,5 \quad(4,4)$

Forkortelse: SD, standard avvik

Tabell 1b: Aldersfordeling for sykepleiestudentene ( $N=83)$

\section{Alder (år)}

$<24$

$29 \quad$ (34.9)

$24-29$

$30-39$

(27.7)

40-49

50-59

Sykepleiergruppen hadde en arbeidserfaring fra 0-26 år med et gjennomsnitt på sju år. Innen sykepleiergruppen var fire kliniske spesialister, ni hadde spesialutdanning og én begge deler. Tabell 1a og $1 \mathrm{~b}$ gir en oversikt over bakgrunnsdata for begge grupper (se tabell $1 \mathrm{a}$ og $1 \mathrm{~b}$ ).

\section{Spørreundersøkelsen}

I denne spørreundersøkelsen varierte sumskår i det samlede utvalget mellom 16 og 37 med 
et gjennomsnitt på 25,2 (64,7 prosent). Sykepleierne hadde en gjennomsnittlig sumskår på 27,7 (71,1 prosent) med en variasjon mellom 19 og 37. Studentene hadde tilsvarende et gjennomsnitt på 22,8 (58,5 prosent) og varierte mellom 16 og 32 . Det betyr at sykepleierne som gruppe svarte nesten 5 poeng bedre enn studentgruppen. Resultatene fra t-testen viste at det var statistisk signifikant forskjell i gjennomsnittlig sumskår mellom sykepleiere og studenter, $\mathrm{t}=8,30, \mathrm{p}<0,001$.

\section{Best besvarte spørsmål}

Tabell 2 viser hvilke spørsmål sykepleier- og studentgruppen hadde flest korrekte svar

Tabell 2: Best besvarte spørsmål.

\section{Påstand / spørsmål (Rett svar uthevet)}

Eldre pasienter tåler ikke opioider som smertelindring (usann).

Den mest korrekte til å bedømme pasientens smerteintensitet er: Pasienten selv*

Barn under 11 år kan ikke rapportere smerter pålitelig. Derfor bør sykepleiere kun stole på foreldrenes vurdering av barnets smerteintensitet (usann).

Etter at den første dosen med et opioid er gitt, bør påfølgende doser justeres i samsvar med den enkelte pasients respons (sann).

Antiepileptika som gabapentin (Neurontin) gir optimal smertelindring etter èn enkelt dose (usann)

Pasienter skal oppmuntres til å tåle så mye smerter som mulig før man bruker et opioid (usann)

En kombinasjon av smertestillende medikamenter med ulik virkningsmekanisme (f.eks. å kombinere et opioid og et NSAID), kan gi bedre smertekontroll og færre bivirkninger, enn bruk av ett enkelt smertestillende medikament (sann).

$\begin{array}{ccc}\begin{array}{c}\text { Totalt rett } \\ \text { besvart } \\ 98 \%\end{array} & \text { Sykepleier } & \begin{array}{c}\text { Sykepleier- } \\ \text { student } \\ 98 \%\end{array} \\ 97.5 \% & 96 \% & 97 \% \\ 95 \% & 96 \% & 94 \% \\ 94.5 \% & 98 \% & 91 \% \\ 92.5 \% & 95 \% & 90 \% \\ 92 \% & 94 \% & 90 \% \\ 90 \% & 92 \% & 88 \%\end{array}$

* Studentgruppen svarte i snitt bedre enn sykepleiergruppen

Tabell 3: Dårligst besvarte spørsmål.

\section{Totalt rett \\ besvart} måneder. I går fikk pasienten Morfin 200 mg/time intravenøst. I dag har han fått $250 \mathrm{mg} / \mathrm{time}$ intravenøst. Sannsynligheten for at pasienten skal utvikle respirasjonsdepresjon av klinisk betydning, uten at det har oppstått ny sykdom, er: Mindre enn $1 \%$

Paralgin Forte (kodeinfosfat $30 \mathrm{mg}$ + paracetamol $400 \mathrm{mg}$ ) tablett har omtrent samme smertestillende effekt som 5 mg morfin tablett (sann).

Hvor sannsynlig er det at pasienter som utvikler smerter, allerede har problemer med alkohol- eller stoffmisbruk? (5-15\%). *

Hvis årsaken til pasientens smerter er ukjent, skal ikke opioider brukes i evalueringsperioden, fordi dette kan maskere muligheten til å diagnostisere årsaken til smerten (usann).
$16 \%$

\section{Sykepleier Sykepleier-} student $9 \%$

$\begin{array}{lll}22 \% & 26 \% & 18 \% \\ 30 \% & 28 \% & 32 \% \\ 31 \% & 43 \% & 19 \%\end{array}$


på. Begge grupper skåret høyt blant annet på at det er pasienten selv som best bedømmer egen smerte, at eldre pasienter tåler opioider og at en multimodal smertelindring kan gi bedre smertekontroll enn bruk av ett enkelt smertestillende legemiddel. (Se tabell 2.)

\section{Dårligst besvarte spørsmål}

De fire spørsmålene som oftest ble besvart feil i sykepleier- og studentgruppen omhandlet blant annet redsel for respirasjonsdepresjon og opioidavhengighet og presenteres i tabell 3 . De neste fire var 2 pasienthistorier med hvert sitt a- og b-spørsmål. Disse presenteres hver for seg nedenfor (se tabell 3).

Følgende pasienthistorie ble presentert og rett svar er uthevet med rosa: "Anders er 25 år gammel, og dette er hans første dag etter operasjonen. I det du kommer inn på rommet, smiler han til deg og fortsetter å snakke og spøke med den som er på besøk. Dine observasjoner viser følgende; $\mathrm{BT}=120 / 80$, hjertefrekvens $=80$, respirasjonsfrekvens $=18$. På en skala fra $0-10$ (hvor $0=$ ingen smerte eller ubehag, $10=$ verst tenkelige smerte / ubehag), angir han sin smerte til 8 .

I pasientens kurve skal du markere hans grad av smerter på skalaen under. Sett kryss $\mathrm{i}$ den boksen du mener representerer din vurdering av Anders' smerter:

\section{$\begin{array}{lllllllllll}0 & 1 & 2 & 3 & 4 & 5 & 6 & 7 & 8 & 9 & 10\end{array}$}

Legens ordinasjon av smertestillende medikament er «Morfin 1-3 mg IV ved behov inntil hver time til smertelindring».

Hvilket tiltak vil du iverksette på dette tidspunktet? Ikke gi morfin foreløpig, Gi morfin 1 mg IV nå, Gi Morfin 2 mg IV nå, Gi morfin $3 \mathrm{mg}$ IV nå.

I alt 37 prosent av sykepleierne og 38 prosent av studentene markerte ved tallet «8», slik pasienten anga sine smerter til å være. Når sykepleieren skulle avgjøre hvilken morfindose pasienten burde få ut fra legens ordinasjon, valgte kun 28 prosent av sykepleierne rett svar, som var å gi $3 \mathrm{mg}$ morfin intravenøst umiddelbart og bare 6 prosent av studentene valgte rett svaralternativ.

Videre ble pasienthistorie nummer 2 presentert nøyaktig lik den forrige, bortsett fra følgende setning: «I det du kommer inn på rommet hans, ligger han rolig $\mathrm{i}$ sengen og lager en grimase i det han snur seg i sengen». Pasienten holdninger til smerte hos voksne i Norge ved bruk av NKAS. Hovedfunnene i studien var at både sykepleiere og sykepleiestudenter hadde gode kunnskaper innen noen områder, men at det fortsatt eksisterte redsel for respirasjonsdepresjon og opioidavhengighet. Videre var det et gap mellom teoretisk kunnskap og praktisk handling synliggjort gjennom to pasienthistorier.

Studien viste at få i utvalget tok hensyn til pasientens egen smertevurdering i de to pasienthistoriene, selv om de tidligere hadde svart at pasienten selv er den som best bedømmer egen smerteintensitet. Dette kan bety at sykepleierne og studentene ikke tok hensyn til pasientens

\section{Kun 12 prosent av studentene valgte å gi $3 \mathrm{mg}$ morfin intravenost, som er rett svaralternativ.}

anga sin smerte også i dette tilfellet til å være «8».

Når pasientens smerteintensitet skulle markeres på NRS-skalaen, valgte 52 prosent av sykepleierne og 46 prosent av studentene «8». Alternativene for smertebehandling var lik som i forrige pasienthistorie. I alt 46 prosent av sykepleierne og kun 12 prosent av studentene valgte å gi 3 mg morfin intravenøst, som er rett svaralternativ. Av de sykepleiere og studenter som valgte å markere ved tallet «8», var det dermed ikke alle som valgte rett dose morfin som smertelindrende tiltak. De sykepleiere og studenter som valgte å gi 3 $\mathrm{mg}$, hadde samtlige notert « 8 » på NRS-skalaen.

\section{DISKUSJON}

Dette er den første studien som evaluerer sykepleieres og sykepleiestudenters kunnskap om og subjektive utsagn i pasienthistoriene. At sykepleieres vurdering av pasientens smerteintensitet ikke alltid stemte overens med pasientens egenvurdering, fremkommer i annen forskning. Pasienter vurderte ofte egen smerteopplevelse til å være høyere enn det sykepleiere vurderte (8,26-28). Intervensjonen ved smertelindring er definert i Nursing Interventions Classification (NIC) som «the alleviation of pain or a reduction in pain to a level of comfort that is acceptable to the patient» (29). Skal effekten av smertebehandlingen vurderes ut fra det som er et akseptabelt smertenivå for pasienten, må sykepleieren lytte til pasienten. Det er derfor bekymringsfullt at så mange av deltakerne i studien valgte et lavere tall enn det pasienten angir $\mathrm{i}$ pasienthistorien, når de skulle 
markere pasientens smertenivå i NRS-skalaen. Ifølge McCaffery og Ferrell er det bare tallet 8 som er rett, fordi det er «det pasienten sier» (20). I en tilsvarende studie i Italia markerte 46 prosernt av 66 sykepleiere «8» der pasienten smiler, og 52 prosent når pasienten snudde seg $\mathrm{i}$ sengen med grimaser (12).

Pasienthistoriene i NKAS avspeilte til en viss grad praksis, og var nyttige for å se om sykepleierne tok hensyn til pasientens opplevelse av smertene. I tillegg ble det synliggjort i hvilken grad sykepleiernes avkryssing av morfindose ble påvirket av beskrivelsen av pasientens atferd. Mange hadde en tilbøyelighet til å ville gi mer morfin til en pasient som viste tegn på smerter, enn til den som smilte. Sykepleierne og studentene tolket pasientens egen smerteopplevelse i lys av forrige dosen anses som ineffektiv $(16,31)$. Når pasientene i pasienthistoriene vurderte smertene til å være fra 6-8 hver halve time etter å ha fått en morfindose på $2 \mathrm{mg}$, har ikke denne dosen hatt ønsket effekt, og burde justeres opp til $3 \mathrm{mg}$. Resultatene synliggjorde en uoverensstemmelse mellom sykepleierne og studentenes kunnskap, og hvordan denne kunnskapen ble anvendt i de to pasienthistoriene. Dihle et al. (10) fant lignende resultater i en norsk studie om postoperativ smertehåndtering. Det ble gjort observasjoner av sykepleiere i praksis, samt intervjuer med sykepleierne i etterkant om den smertebehandlingen som ble utført. Studien avdeket at sykepleierne hadde bedre kunnskaper teoretisk, enn det de praktiserte overfor pasienter med smerter (10). Dette viste at

\section{Det er viktig å vite at behovet for opioider reduseres når smertene avtar.}

pasienthistorienes beskrivelse av atferd. McCaffery og Beebe understreker at pasientens atferd kan være et forsøk på å avlede og utholde smertene (31). Svarene fra pasienthistoriene viste at mange av sykepleierne og studentene valgte å gi en ineffektiv dose, eller avsto fra å ville gi morfin enn så lenge. Det betyr at de ville ha latt pasienten ha så sterke smerter som 8 på en skala fra $0-10$. Dette til tross for at så mange som 98 prosent av sykepleierne og 91 prosent av studentene svarte at når et opioid var gitt, burde påfølgende dose blitt justert etter pasientens respons. Ifølge McCaffery, Pasero og Ferrell skal dosen med opioider økes med 25-50 prosent når den holdningsendringer og kunnskapsøkning var nødvendig, tansen innen smertebehandling. Bruk av NKAS i sykepleierutdanningen og på sykehus kan synliggjøre områder med svak kompetanse. Undervisning kombinert med veiledning i reelle pasientsituasjoner kan være hensiktsmessig for å bedre smertelindringen til kirurgiske pasienter og pasienter med kreftsykdom. Forhåpentligvis kan det gi sykepleieren større trygghet og pasienten bedre smertelindring.

\section{Opiofobi}

Når sykepleierne krysset av ved en ineffektiv dose, eller valgte ikke å gi mer morfin selv om i den hensikt å styrke kompe- pasienten hadde smerter, kan det skyldes en bekymring for at pasienten skulle utvikle medikamentavhengighet. Denne "opiofobien» medførte en overforsiktighet ved administrering av opioider $(9,14,17)$. Imidlertid skal redselen for en fremtidig avhengighet ikke hindre sykepleieren $\mathrm{i}$ å smertelindre med en effektiv dose (32). Det er viktig å vite at behovet for opioider reduseres når smertene avtar, som etter et kirurgisk inngrep og i mer stabile faser av kreftsykdom. Mindre enn 1 prosent av pasienter får et avhengighetsproblem som følge av smertebehandling $(30,33)$. At sykepleiere administrerte lavere doser opioider enn hva som var ordinert "ved behov", fremkom også i internasjonal forskning $(9,13,34)$.

Respirasjonsdepresjon forekommer sjelden hos pasienter som har fått stabile doser med opioider i flere måneder (31). Dette visste 82 prosent av sykepleierne og 46 prosent av studentene. I et senere spørsmål settes denne problemstillingen inn i en klinisk sammenheng. Nå var det bare 23 prosent av sykepleierne og 9 prosent av studentene som visste at faren for respirasjonsdepresjon er minimal. Selv om morfindosen i eksemplet er høy, er økningen kun 25 prosent, som anbefalt. Totalt sett viste sykepleierne og studentene at de hadde grunnleggende kunnskap. Praksiseksempelet viste imidlertid at de hadde problemer med å bruke den.

McCaffery har definert smerte som «Pain is whatever the experiencing person says it is, existing whenever he says it does» (35). Det er viktig at sykepleieren erkjenner at «smerte er det pasienten sier at 
det er». Det er kun personen selv som kan kjenne smertens lokalisering, intensitet og hyppighet. At smerte er en subjektiv opplevelse bekreftes av den internasjonale smerteforeningen IASP, som i 1979 definerte smerte som «an unpleasant sensory and emotional experience associated with actual or potential tissue damage or described in terms of such damage» (2). Smerteopplevelsen knyttes til en aktuell eller mulig vevsskade, eller noe som kan kjennes ut som dette. For dårlig smertelindring kan føre til psykologiske og fysiologiske komplikasjoner, samt bidra til utvikling av kroniske smerter $(36,37)$.

Sykepleierne og sykepleiestudentene i studien visste at det er pasienten selv som best kan kjenne og bedømme smerteintensiteten. Dette ble synliggjort ved at 96 prosent av sykepleierne og så mange som 99 prosent av studentene krysset av for «pasienten selv» og dermed svarte rett på spørsmålet om hvem som best kan bedømme pasientens smerteintensitet. Det er betryggende at svært få krysset av for legen, primærsykepleieren eller familien. På spørsmålet om den mest sannsynlige forklaringen på at en pasient ba om økt dose smertestillende medikament, svarte 94 prosent av sykepleierne og 83 prosent av studentene at det var fordi pasienten opplevde økte smerte. Underforstått at det dermed ikke skyldes angst, oppmerksomhetsbehov eller medikamentavhengighet.

\section{Begrensninger}

Selv om funnene gikk i samme retning som lignende internasjonale studier med bruk av NKAS $(12,34,38,39)$, er de ikke nødvendigvis representative for alle sykepleiere i Norge. En svakhet ved studien var at utvalget kun var hentet fra ett universitetssykehus og én høyskole innenfor én helseregion. Studien ble gjennomført i 2009 og man kan heller ikke utelukke at endringer i praksis og undervisning ville gitt

\section{Implikasjoner for praksis}

Det å kartlegge kunnskaper og holdninger er ikke nok, men resultater fra kartleggingsstudier gir en mulighet til å identifisere områder for forbedring. Å heve kunnskapsnivået og styrke holdningene til sykepleiere og studenter, vil kunne komme pasientene til gode.

\section{«Opiofobien» medforte en overforsiktighet ved administrering av opioider.}

et annet resultat om studien hadde blitt gjennomført i dag. At sykepleierne var rekruttert fra kirurgiske avdelinger som forholdsvis ofte benyttet opioider som smertelindring, kan ha påvirket resultatene. Sykepleierne i denne studien kan dermed ha flere riktige svar enn om utvalget hadde blitt rekruttert fra andre typer avdelinger.

\section{Konklusjon}

Resultatene fra studien viste at mange fortsatt frykter respirasjonsdepresjon og opioidavhengighet. Videre var det et gap mellom teoretisk kunnskap og praktisk handling synliggjort gjennom to pasienthistorier. På noen områder innen smertelindring viste sykepleiere og sykepleiestudenter at de hadde god kunnskap og gode holdninger.

Studien synliggjorde et behov for å styrke kompetansen, slik at sykepleiere og studenter kan bli dyktigere til å håndtere pasientens smerter. Undersøkelsen avdekket at sykepleiere og studenter må bli flinkere til å ta hensyn til det pasienten uttrykker, synliggjort gjennom pasienthistorien. Videre må sykepleiere og studenter forbedre kunnskapen om og fornye holdningene til smertebehandling med opioider.
Denne undersøkelsen i seg selv var ikke omfattende nok til å kunne generalisere på landsbasis, men ga indikasjoner som kan følges opp med lignende studier. Nye studier kan danne grunnlag for kompetanseheving innen utdanning, opplæring i praksis og for videre forskning. NKAS har blitt validert og er nå tilgjengelig på norsk. Dermed kan kartlegging av sykepleieres kunnskaper om og holdninger til smerter gjennomføres i flere sammenhenger, både lokalt og nasjonalt.

Takk til avdelingsledere, sykepleiere og sykepleiestudenter som giorde denne studien mulig.

\section{REFERANSER}

1. Den norske legeforening. Retningslinjer for smertebehandling i Norge. Den norske legeforening 2009. http:// legeforeningen.no/pagefiles/42355/retningslinjer $\% 20$ smertebehandling $\% 20$ dnlf.pdf. (Nedlastet 26.01.2015).

2. International Association for the Study of Pain (IASP). http://www.iasppain.org/Taxonomy?navltem Number $=576$ (Nedlastet 26.01.2015).

3. Dihle A. Smerte og smertelindring. I: Hovind IL (red.). Anestesisykepleie. Akribe AS, Oslo 2011 (s. 95-117).

4. Carr E. Barriers to effective pain management. Journal of Perioperative Practice. 2007;17:200.

5. Carr ECJ, Meredith P, Chumbley 
G, Killen R, Prytherch DR, Smith GB Pain: A quality of care issue during patients> admission to hospital. Journal of Advanced Nursing. 2014;70:1391-403. 6. Francis L, Fitzpatrick JJ. Postoperative Pain: Nurses' Knowledge and Patients' Experiences. Pain Management Nursing. 2013;14:351-7.

7. Taylor A, Stanbury L. A review of postoperative pain management and the challenges. Current Anaesthesia \& Critical Care. 2009;20:188-94.

8. Yildirim YK, Cicek F, Uyar M. Knowledge and attitudes of Turkish oncology nurses about cancer pain management. Pain Management Nursing: Officia Journal of the American Society of Pain Management Nurses. 2008;9:17-25.

9. Coulling S. Nurses> and doctors knowledge of pain after surgery. Nursing Standard. 2005 5/4:19:41-9.

10. Dihle A, Bjolseth G, Helseth S. The gap between saying and doing in postoperative pain management. Journal of Clinical Nursing. 2006;15:469-79.

11. Apfelbaum JL, Chen C, Mehta SS, Gan TJ. Postoperative pain experience: results from a national survey suggest postoperative pain continues to be undermanaged. Anesthesia and analgesia. 2003;97:534-40

12. Bernardi M, Catania G, Tridello G. Knowledge and attitudes about cancer pain management: a national survey of Italian hospice nurses. Cancer Nursing. 2007:30:E20-6.

13. Lorentzen V, Hermansen IL, Botti M. A prospective analysis of pain experience, beliefs and attitudes, and pain management of a cohort of Danish surgical patients. European Journal of Pain. 2012;16:278-88.

14. Auret K, Schug SA. Underutilisation of opioids in elderly patients with chronic pain. Drugs \& Aging. 2005;22:64154.

15. Cullen L, Greiner J, Titler MG. Pain management in the culture of critical care. Critical care nursing clinics of North America. 2001:13:151-66.

16. McCaffery M, Ferrell BR, Pasero C Nurses> personal opinions about patients> pain and their effect on recorded assessments and titration of opioid doses. Pain Management Nursing. 2000;1:79-87.

17. Brennan F, Carr DB, Cousins M Pain Management: A Fundamental Human Right. Anesthesia \& Analgesia. 2007;105:205-21.

18. Rognstad M-K, S, Johannessen TEB, Kvarstein G, Skauge M, Undall $E$, et al. Attitudes, beliefs and selfreported competence about postoperative pain among physicians and nurses working on surgical wards. Scandinavian Journal of Caring Sciences. 2012;26:545-52.

19. Skauge M, Borchgrevink PC, Kaasa
S. [Self-evaluation of knowledge and competence with regard to the treatment of pain]. Tidsskrift for Den norske legeforening. 1998;118:536-40.

20. Ferrell B, McCaffery M. Nurses' Knowledge and Attitudes Survey Regarding Pain. (http://prc.coh.org) City of Hope, California 2014.

21. Beaton DE, Bombardier C, Guillemin F, Ferraz MB. Guidelines for the process of cross-cultural adaptation of self-report measures. Spine. 2000;25:3186-91

22. Guillemin F, Bombardier C, Beaton D. Cross-cultural adaptation of healthrelated quality of life measures: literature review and proposed guidelines. Journal of Clinical Epidemiology. 1993:46:1417-32

23. Koller M, Aaronson NK, Blazeby J, Bottomley A, Dewolf L, Fayers P, et al. Translation procedures for standardised quality of life questionnaires: The European Organisation for Research and Treatment of Cancer (EORTC) approach. European Journal of Cancer. 2007:43:1810-20.

24. Granheim TH. Den norske versjonen av «Nurses» Knowledge and Attitudes Survey Regarding Pain»: oversettelse, reliabilitet og validering. Masteroppgave i klinisk sykepleievitenskap, Avdeling for sykepleierutdanning. Høgskolen i Oslo. 2009.

25. Sykepleiernes Samarbeid i Norden. Etiske retningslinjer for sykepleieforskning i Norden. 2003.

26. Ene KW, Nordberg G, Bergh I, Johansson FG, Sjöström B. Postoperative pain management - the influence of surgical ward nurses. Journal of Clinical Nursing. 2008;17:2042-50.

27. Sloman R, Rosen G, Rom M, Shir Y. Nurses' assessment of pain in surgical patients. Journal of Advanced Nursing. 2005:2:125-32

28. Gunningberg L, Idvall E. The quality of postoperative pain management from the perspectives of patients, nurses and patient records. Journal of Nursing Management. 2007;7:756-66

29. Bulechek GM, Butcher HK, McCloskey Dochterman JM, Wagner C. Nursing interventions classification (NIC) 6th ed. ed. St. Louis: Elsevier; 2013.

30. McCaffery M, Beebe A. Smerter. Lærebok for helsepersonell. Oslo: Gyldendal Akademisk; 2001.

31. McCaffery M, Pasero C, Ferrell BR. Nurses> Decisions About Opioid Dose. A JN The American Journal of Nursing. 2007;107:35-9.

32. McCaffrey M, Ferrell BR. Nurses> knowledge of pain assessment and management: How much progress have we made? Journal of Pain and Symptom Management. 1997:14:17588

33. Marks RM, Sachar EJ. Undertreat- ment of medical inpatients with narcotic analgesics. 1973;78:173-81.

34. Matthews E, Malcolm C. Nurses> knowledge and attitudes in pain management practice. British Journal of Nursing. 2007:16:174-9.

35. McCaffery M. Nursing the Patient in Pain. London: Harper and Row Publishers Ltd.; 1983.

36. Kehlet H, Jensen TS, Woolf CJ. Persistent postsurgical pain: risk factors and prevention. Lancet. 2006;367:161825.

37. Katz J, Seltzer Z. Transition from acute to chronic postsurgical pain: risk factors and protective factors. Expert Review of Neurotherapeutics. [Review]. 2009:9:723-44.

38. Lui LYY, So WKW, Fong DYT. Knowledge and attitudes regarding pain management among nurses in Hong Kong medical units. Journal of Clinical Nursing. 2008;17:2014-21.

39. Plaisance L, Logan C. Nursing students $>$ knowledge and attitudes regarding pain. Pain Management Nursing. 2006;7:167-75

Les kommentaren på side 335 》> 